\title{
KAJIAN KLASIFIKASI BERBASIS OBYEK UNTUK PEMETAAN BANGUNAN YANG BERISIKO GEMPABUMI DI BANTUL, DAERAH ISTIMEWA YOGYAKARTA
}

\author{
Lewi Ristiyono ${ }^{1}$, Projo Danoedoro ${ }^{2}$ dan Muh. Aris Marfai ${ }^{3}$
}

Badan Meteorologi Klimatologi, dan Geofisika Medan, Sumatera Utara, Indonesial, Fakultas Geografi,Universitas Gadjah Mada, Yogyakarta, Indonesia ${ }^{2,3}$

Lewi_r@yahoo.co.id

Diterima : September 2015; Direvisi: Januari 2015; Dipubikasikan: Maret 2016

\begin{abstract}
ABSTRAK Bencana gempabumi mengakibatkan kerusakan bangunan dan infrastruktur. Oleh karena itu perlu adanya pemetaan bangunan dan infrastruktur yang menjadi elemen berisiko gempabumi. Dikarenakan daerah yang terdampak gempabumi di indonesia sangatlah luas maka pemetaan bangunan dan infrastruktur memerlukan teknologi penginderaan jauh. Teknologi penginderaan jauh dengan klasifikasi penggunaan lahan mampu memetakan bangunan dan infrastruktur lebih efisien. Klasifikasi penggunaan lahan dengan pendekatan berbasis piksel memiliki kelemahan yaitu mengabaikan aspek spasial, munculnya "salt and papper" dan kurang menunjukan otomatis ketika diintegrasikan dengan SIG. Kelemahan klasifikasi berbasis piksel tersebut dilengkapi pada klasifikasi berbasis objek. Penelitian ini bertujuan Penelitian ini bertujuan mengkaji kemampuan klasifikasi berbasis objek dengan menggunakan citra ALOS pansharpening dalam memetakan bangunan dan infrastruktur yang berisiko gempabumi. Metode yang digunakan dalam klasifikasi berbasis objek dengan klasifikasi hierarkis rule-based dengan segmentasi multiresolusi. Metode ini memanfaatkan algoritma hierarchical classification dan logika fuzzy yang disusun dalam rule-set ditiap kelas penggunaan lahan. Logika fuzzy digunakan untuk menentukan nilai keanggotaan fitur-fitur objek yang digunakan dalam identifikasi objek dalam citra. Fitur-fitur objek yang digunakan adalah gabungan dari aspek spektral dan tekstur atau GLCM. Nilai fitur-fitur objek diekstrak dari sempel area berdasarkan segmentasi multiresolusi dengan citra multispektral AVNIR-2 pansharpening. Selanjutnya hasil klasifikasi penggunaan lahan diseleksi subkelas area terbangunan dimanfaatkan untuk mengetahui distribusi spasial bangunan yang berisiko gempabumi. Hasil dari klasifikasi menunjukan tingkat akurasi yang rendah dimana akurasi keseluruhan yang dihasilkan adalah $65.4 \%$ dan akurasi klasifikasi untuk subkelas area terbangun juga rendah. Hal ini disebabkan oleh kurang efektiknya klasifikasi hierarkis pada daerah penggunaan lahan dengan heterogenitas yang tinggi, distorsi citra AVNIR-2 pansharpening sebagai sumber data. Dan penggunaan 1 skala segmentasi untuk semua kelas di level 4 klasifikasi mempengaruhi rendahnya akurasi klasifikasi berbasis objek.
\end{abstract}

Kata kunci: ALOS pansharpening; bangunan; gempabumi; klasifikasi berbasis objek; klasifikasi hirarki.

ABSTRACT The earthquake caused damage to buildings and infrastructure. Therefore, it is necessary to buildings and infrastructure mapping the earthquake risk element. Due to the earthquake affected areas in Indonesia is very broad, the mapping of buildings and infrastructure require remote sensing technology. Remote sensing technology to land use classification able to map more efficient buildings and infrastructure. Land use classification with pixel-based approach has the disadvantage of ignoring the spatial aspect, the emergence of "salt and papper" and less to show automatically when integrated with GIS. The pixel-based classification weakness comes on object-based classification. The aim of this study aims to assess the ability of this research-based classification of objects by using ALOS pansharpening in mapping of buildings and infrastructure at risk of earthquakes. The method used in object-based classification with rule-based hierarchical classification with multiresolution segmentation. This method utilizes a hierarchical classification algorithms and fuzzy logic are compiled in rule-sets in each class of land use. Fuzzy logic is used to determine the value of the membership features of objects used in the identification of objects in the image. Features of the object used is a combination of spectral and texture aspects or GLCM. The value of the object is extracted features of a sample of area based segmentation of multiresolution with multispectral image AVNIR-2 pansharpening. Furthermore, the results of the land use classification subclass selected terbangunan area used to determine the spatial distribution of earthquake-risk buildings. Results from the classification indicates a low degree of accuracy where the resulting overall accuracy was $65.4 \%$ and the accuracy of the classification to subclass the area woke up too low. It is caused by a lack of hierarchical classification efektiknya on the area of land use with high heterogeneity, image distortion AVNIR-2 pansharpening as a data source. And use 1 scale segmentation for all classes at level 4 classification affect the low accuracy of object-based classification.

Keywords: ALOS pansharpening; building; earthquakes; object-based classification; classification hierarkies.

\section{PENDAHULUAN}

Gempabumi tidak lagi dipandang sebagai fenomena alam biasa namun dapat menjadi sumber bencana. Oleh karena itu perlu managemen bencana gempabumi. Salah satu bentuk managemen bencana gempabumi adalah dengan melakukan penilaian risiko gempabumi. Penilaian risiko gempabumi dikaji untuk mengetahui dimana dampak terburuk gempabumi dan mengurangi dampak bencana tersebut. Penilaian risiko berbasis spasial berdasarkan perumusan oleh Varnes 
(1984) yaitu fungsi dari bahaya (H), kerentanan (V) dan elemen berisiko (E) yaitu $\mathrm{R}=(\mathrm{E})(\mathrm{HxV})$. Dilihat dari fungsi tersebut maka diperlukan data spasial elemen berisiko selain data spasial bahaya dan kerentanan. Jika dilihat sumber bencananya yaitu gempabumi maka elemn berisiko adalah bangunan dan infrastruktur. Pemetaan bangunan dan infrastruktur diperlukan sebagai data spasial elemen berisiko. Tersedianya data spasial elemen berisiko gempabumi akan memudahkan dalam perkiraan korban jiwa, kerugian, luas area yang terdampak akibat gempabumi.

Pemetaan bangunan dan infrastruktur dapat dilakukan melalui survei lapangan maupun melalui data penginderaan jauh. Pendekatan melalui penginderaan juah lebih efektif dibandingan survei lapangan. Bangunan dan infrastruktur yang menjadi elemen berisiko gempabumi merupakan bagian dari informasi penutup lahan dan penggunaan lahan pada citra penginderaan jauh (Westen et al., 2011). Informasi penutup lahan dan penggunaan lahan diperoleh dengan klasifikasi penutup lahan dan penggunaan lahan. Pendekatan klasifikasi penutup lahan dapat menjadi metode dalam pemetaan bangunan dan infratruktur.

Klasifikasi penutup dan penggunaan lahan dapat dilakukan dengan pendekatan berbasis piksel dan berbasis objek. Interpretasi berbasis piksel merupakan pendekatan tradisional yang sudah mapan. Namun pendekatan berbasis piksel memiliki kelemahan yaitu interpretasi berbasis piksel mengabaikan unsur spasial sehingga mengurangi akurasi (Hay dan Castilla, 2008; Blaschke et al., 2014), adanya "salt and pepper" pada hasil klasifikasi terutama dari citra resolusi tinggi (Blaschke, 2010), kurangnya menunjukkan tingkat otomasi yang tinggi ketika klasifikasi yang melibatkan data nir-spektral dalam bentuk integrasi dengan SIG (Danoedoro, 2012). Pendekatan berbasis objek merupakan usaha dalam menutupi kelemahan berbasis piksel. Pendekatan berbasis objek dengan segmentasi memiliki kelebihan yaitu mengkombinasikan infromasi spektral dan spasial sebagai indikator pengembangan klasifikasi landuse Blaschke (2010), objek geografis dibedakan tidak hanya berdasarkan aspek spektral saja tetapi juga aspek spasial seperti bentuk, pola dan teksturnya Danoedoro (2012), merupakan solusi yang layak untuk mengurangi modifiable areal unit problem (MAUP) oleh Openshaw (1984) dalam Hay dan Castilla (2008), memberikan akurasi yang lebih baik dibandingkan klasifikasi berbasis piksel Soe W., et al. (2011); Timothy et al., (2011), lebih konsisten dalam penerapan multitemporal (Mitchell B., et al., 2012). Pendekatan berbasis objek semakin berkembang dengan didukungan perkembangan metode segmentasi. Segmentasi ECHO (Extraction and Classification of Homogeneous Object) memberikan akurasi yang relatif rendah pada dimensi spasial (Danoedoro, 2012). Metode segmentasi yang berbasis region growing dinilai lebih handal dibandingkan yang metode yang lain (Gorte, 1998; Molenaar, 1998; Baatz \& Schäpe, 2000; dalam Blaschke et al., 2004). Metode segmentasi multiresolusi adalah metode segementasi berbasis region growing lebih berkembang karena memasukan parameter spektral dan spasial secara bersamaan dan memberi akurasi yang lebih baik (Burnett dan Blaschke 2003; Benz et al., 2004; Danoedoro 2012), mendukung konsep hierarki objek, multiskala (Burnett dan Blaschke 2003; Blaschke et al., 2014). Dilihat dari kelebihan klasifikasi berbasis objek tersebut maka klasifikasi berbasis objek lebih diperlukan dibandingkan berbasis piksel.

Pendekatan berbasis objek dengan segmentasi multiresolusi memiliki kelemahan. Segmentasi multiskala dengan hirarki objek dimungkinkan menurunkan kesalahan, over atau under segmentasi Schiewe, I. (2002) yang dapat mengurangi tingkat akurasi klasifikasi penutup lahan dan pengunaan lahan (Masroor Hussain et al., 2013). Oleh karena itu pendekatan klasifikasi berbasis objek (OBIA/GEOBIA) dengan metode segmentasi multiskala perlu dikaji akurasinya dalam menurunkan informasi penutup lahan dan penggunaan lahan untuk mendapatkan elemen berisiko gempabumi.

Pemetaan bangunan dan infrastruktur dengan pendekatan berbasis objek memerlukan citra dengan resolusi tinggi. Citra resolusi tinggi dapat diperoleh dengan metode pansharpening citra multispektral dan pankromatik. Citra pankromatik ALOS memiliki resolusi 2,5 m merupakan citra dengan katagori citra resolusi tinggi. Citra ALOS pansharpening akan menghasilkan citra multispektral dengan resolusi 2,5 m. Dengan demikian citra ALOS pansharpening diperlukan dalam klasifikasi berbasis objek untuk pemetaan bangunan dan infrastruktur.

Penelitian ini bertujuan untuk mengkaji akurasi pendekatan klasifikasi berbasis objek (OBIA) dengan citra ALOS pansharpening. Dan pemetaan bangunan dan infrastruktur yang berisiko gempabumi melalui ekstrasi informasi klasifikasi penutup lahan dan penggunaan lahan dengan pendekatan klasifikasi berbasis objek.

\section{METODE PENELITIAN}

Metode yang digunakan dalam klasifikasi berbasis objek adalah klasifikasi hierarkis berdasarkan rule set dengan segmentasi multiresolusi. Alur kerja dalam 
penelitian menurut diagram alir pada Gambar 1. Citra yang digunakan adalah citra ALOS AVNIR-2 dan Prism tanggal observasi 20 Juni 2009, Peta RBI kabupaten Bantul dengan skala 1:25.000 sebagai acuan dalam koreksi geometrik, Peta Geologi Lembar Yogyakarta skala 1:100.000.

\section{Tahap Pansharpening}

Pansharpening adalah teknik untuk meningkatkan resolusi spasial citra multispektral dengan fusion citra pankromatik. Tahapan ini akan menggabungkan citra ALOS AVNIR-2 dengan citra PRISM. Citra AVNIR-2 yang memiliki resolusi spasial $10 \mathrm{M}$ akan menjadi citra AVNIR-2 dengan resolusi 2,5 M. Hasil dari tahap ini adalah AVNIR-2 pansharpen yang akan digunakan dalam proses segmentasi dan klasifikasi penggunaan lahan.

Algoritma pansharpen yang digunakan adalah algoritma GS (Gram-Schmidt). Alasan penggunaan algoritma tersebut berdasar hasil penelitian (Witharana et al., 2014). Penelitian tersebut menyatakan bahwa algoritma GS memberikan hasil yang baik ketika digunakan dalam segmentasi dan klasifikasi berbasis objek dibandingkan algoritma pansharpen yang lain.

\section{Tahap Koreksi Geometrik}

Koreksi geometrik adalah tahap persiapan data untuk siap diolah. Tujuan dari koreksi geometrik adalah untuk menghasilkan informasi yang memiliki akurasi geometris yang tinggi. Koreksi geometri dilakukan dengan rektifikasi citra ke peta. Teknik ini dengan menggunakan titik kontrol lapangan (ground control point, GCP) dari peta RBI.

\section{Tahap Segmentasi}

Tahap segmentasi pada penelitian ini menggunakan metode Multiscale Segmentation/Object Relationship Modelling (MSS/ORM) yang dikenalkan oleh Burnett dan Blaschke, (2003). Metode tersebut memanfaatkan segmentasi multiresolusi dengan hierarki objek. Segmentasi multiskala terdapat parameter utama yaitu skala, spektral/warna, bentuk yang terdiri dari kekompakan (compactness) dan kehalusan (smoothness).

Parameter skala adalah threshold dalam proses iterasi segmentasi multiskala atau sebagai penentu piksel-piksel yang bergabung membentuk objek dan penentu banyaknya sub-objek yang bergabung membentuk super-objek (Benz et al., 2004). Penentuan parameter skala adalah berdasarkan trial and error. Penelitian ini menggunakan tool yang diusulkan Drăguţ et al. (2010) untuk memperkirakan nilai dari parameter skala segmentasi.

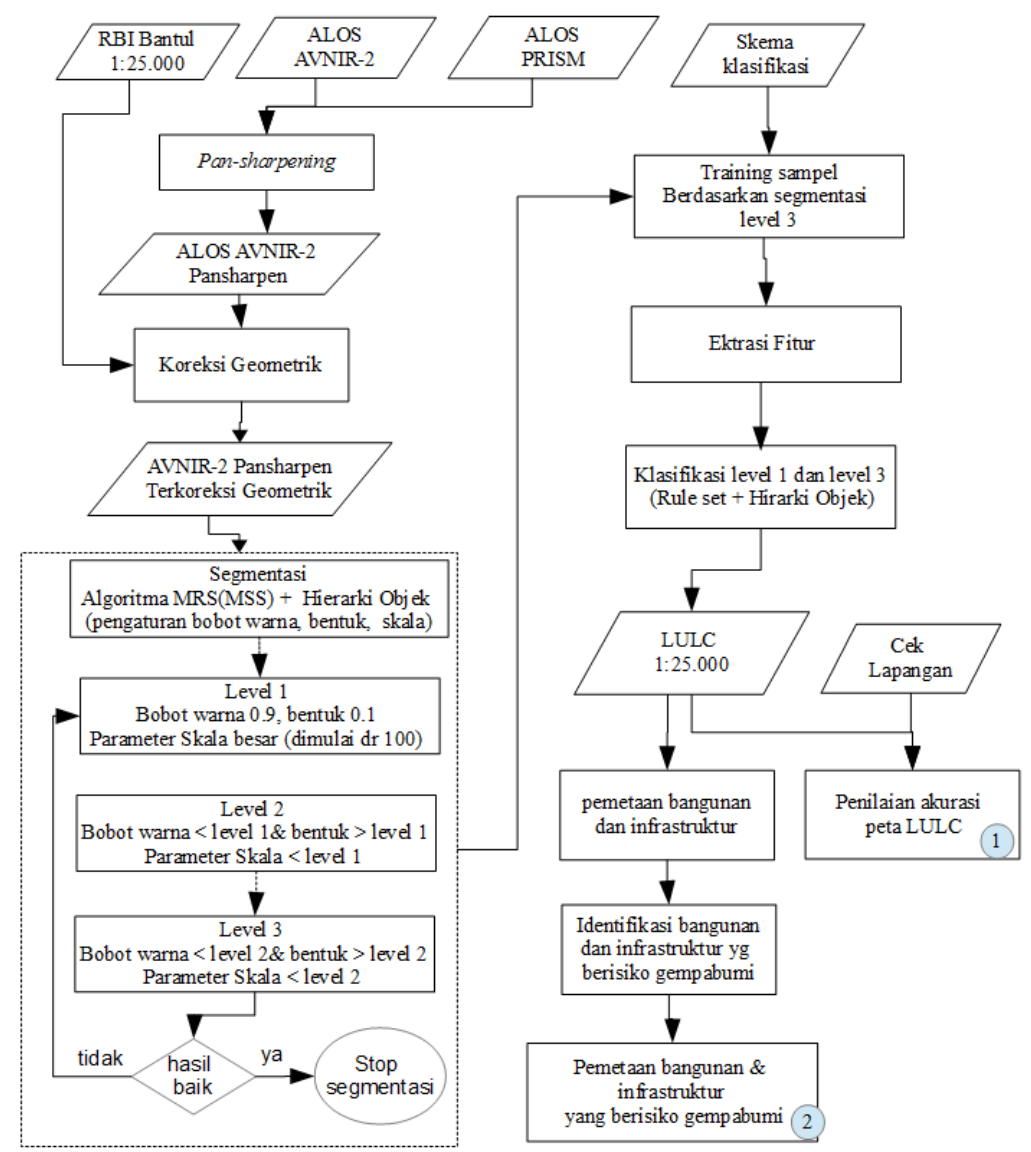

Gambar 1. Diagram Alir Metode Penelitian 
Nilai parameter spektral atau warna $\left(\mathrm{w}_{\mathrm{c}}\right)$ memiliki bobot 0.0 - 1.0 dan bobot parameter bentuk sebesar 1 $\mathrm{w}_{\mathrm{c}}$. Pemberian bobot parameter spektral dan bentuk berdasarkan trial and error. Sebagai pertimbangan dalam pemberian bobot tersebut, pada level 1 objek dalam citra memiliki karakteristik spektral yang dominan dibandingakn bentuk oleh karena itu diberi bobot spektral 0.9 dan bentuk 0.1. Level berikutnya karakteristik spektral berkurang dan bentuk bertambah. Indikator segmentasi tersebut baik adalah objek yang tersegmen mendekati sesuai dengan objek pada skema klasifikasi. Segmentasi dengan hierarki objek menuntut proses segmentasi yang bertahap dari level 1 sampai level selanjutnya. Dan tiap level memiliki target skala yang sudah disiapkan dan disesuaikan dengan skema klasifikasinya. Level 1 pada proses segmentasi ditujukan untuk skema klasifikasi level 1 dengan target skala 1:1.000.000. Level 2 pada proses segmentasi ditujukan untuk skema klasifikasi level 2 dengan target skala propinsi yaitu 1:250.000 dan level 3 proses segmentasi ditujukan untuk skema klasifikasi level 3 dengan target skala 1:50.000 atau 1:25.000.

\section{Tahap Klasifikasi}

Tahapan klasifikasi berbasis objek adalah tahap mengartikan objek dalam citra yang telah tersegmen. Metode yang digunakan klasifikasi berbasis objek pada penelitian ini adalah klasifikasi hierarkis rule-based. Metode ini menggunakan algoritma hierarchical classification dan rule-set untuk pelaksanaan proses klasifikasi. Proses klasifikasi terdiri dari 3 rangaian proses yaitu pengambilan training area, ekstrasi fitur dan membangun rule set untuk klasifikasi.

Training area diambil berdasarkan hasil segmentasi. Segmen yang digunakan dalam training area adalah segmentasi level 3. Segmentasi level 3 digunakan sebagai target klasifikasi level 4. Pengambilan training area sebanyak kelas penggunaan lahan yang digunakan pengambilan training area ini harus dilaksanakan secara selektif sehingga dapat mewakili kelas penggunaan lahan dan meningkatkan akurasi.

Ekstrasi fitur merupakan proses untuk mendapatkan nilai atribut objek-objek penutup lahan dan penggunaan lahan. Pengambilan fitur ini berdasarkan dari training area yang sudah ditentukan sebelumnya. Nilai dari atribut objek sampel ini dihitung ditentukan fungsi fuzzy untuk derajat keanggotaannya.

Proses selanjutnya yaitu membangun rule set berdasarkan atribut kelas objek penutup dan penggunaan lahan. Objek level 1 lebih bersifat spektral oleh karena itu penggunaan fitur objek yang digunakan adalah NDVI, NDWI, BAI, Brightness. Berdasarkan rule set yang telah tersusun tersebut maka proses klasifikasi dapat dilakukan.

Proses klasifikasi dimulai pada level 1 klasifikasi yang terdiri 4 kelas seperti terlihat dalam lampiran 1. Fitur objek yang digunakan adalah gabungan dari aspek spektral yaitu NDVI, NDWI, BAI, Brightness, Ratio dan aspek spasial yaitu GLCM atau tekstur. Proses klasifikasi level 1 ini menggunakan algoritma classification yang ditulis pada jendela process tree seperti gambar 3.5 jendela process tree ini digunakan untuk menulis proses klasifikasi dengan menentukan algoritmanya. Setelah proses klasifikasi level 1 selesai dilanjutkan dengan klasifikasi level 4 yang jadi target akhir klasifikasi pada penelitian ini. Klasifikasi level 4 menggunakan algoritma Hierarchical Classification. Fitur yang digunakan adalah gabungan dari aspek spektral dan spasial ditambah dengan bentuk dan ukuran untuk kelas bangunan. Gabungan fitur-fitur ini untuk mendeskripsikan kelas penggunaan lahan diharapkan menghasil klasfikasi penggunaan lahan dengan akurasi yang tinggi.

\section{Tahap Lapangan}

Unit analisis yang digunakan dalam tahap lapangan adalah kelas penggunaan lahan. Kelas penggunaan lahan dijadikan unit analisis karena dalam penelitian ini mengkaji klasifikasi LULC dengan pendekatan berbasis objek untuk pemetaan bangunan yang berisiko gempabumi. Kelas penggunaan lahan yang dipakai sesuai dengan skema klasifikasi yang digunakan dalam penelitian ini.

Metode yang digunakan pengambilan data lapangan adalah stratified random sampling. Metode ini sebelumnya menyusun kelas data dalam tingkatan misalnya jumlah piksel yang sedikit sampai dengan yang banyak. Maksud dari pengaturan tingkat kelas adalah pengambilan data yang seimbang antara tingkat yang tertinggi sampai terendah.

Berdasar unit analisis dan metode pengambilan data dilakukan pengambilan data lapangan. Data lapangan diambil berdasarkan kelas penggunaan lahan dengan jumlah yang sebanding dengan luas atau jumlah piksel tiap kelas penggunaan lahan. Dengan demikian tiap kelas terwakili sesuai dengan luas tiap kelas penggunaan lahan. tahap lapangan mendapatkan data sempel dan data validasi dengan demikian menghemat waktu dan biaya survei.

\section{Tahap Penilaian Akurasi/Validasi Peta Klasifikasi}

Tahap ini akan menilai akurasi peta klasifikasi yang dihasilkan dengan pendekatan MSS/ORM. Penilaian akurasi dengan menggunakan matrik kesalahan (confusion matrix). Cara pengujian akurasi klasifikasi 
merujuk pada metode (Short, 1982) dalam Danoedoro, 2012). Metode ini melihat akurasi dari dua sisi yaitu sisi penghasil peta (producer's accuracy) dan pengguna peta (user's accuracy). Hasil dari tahap ini adalah persentase kebenaran hasil klasifikasi dari sisi penghasil peta, pengguna peta maupun akurasi keseluruhan. Persentase kebenaran ini dapat menjadi tingkat keberhasilan dalam metode klasifikasi. Dengan demikian informasi yang diberikan diketahui tingkat kesalahan.

\section{Tahap Pemetaan Bangunan dan Infrastruktur}

Tahap ini akan melakukan proses pemetaan bangunan dan infrastruktur. Proses pemetaan dilakukan dengan seleksi kelas bangunan dari peta klasifikasi penutup dan penggunaan lahan. Hasil yang diperoleh adalah peta bangunan dan infrastruktur yang isinya sesuai dengan kelas bangunan pada level 4 skema klasifikasi penggunaan lahan. Peta bangunan dan infrastruktur ini memiliki skala 1:50.000 atau skala kabupaten. Skala peta yang dihasilkan sesuai dengan peta penggunaan lahan yang dihasilkan dari tahap sebelumnya.

\section{Tahap Identifikasi Bangun dan Infrastruktur yang Berisiko Gempabumi}

Tahapan ini merupakan penilaian resiko area terbangun terhadap gempabumi. Penilaian resiko yang diterapkan sesuai dengan perumusan yang dijabarkan oleh (Varnes, 1984). Alasan penggunaan metode ini adalah hasil pemetaan bangunan dan infrastruktur masih memiliki kapasitas yang sama dalam menghadapi gempabumi. Dengan demikian penilaian resiko ditentukan oleh penilaian kerentanan gempabumi.

Penilaian kerentanan gempabumi yang digunakan dalam tahap ini adalah pendekatan litologi dan bentuklahan. Hal ini sesuai berdasarkan penelitian Daryono (2011) dimana bentuklahan dan litologi memiliki hubungan terhadap kerentanan seismik. Daerah dengan litologi Pasir, kerikil, lempung memiliki kelas kerentanan seimik lebih rentan. Dan daerah dengan litologi batupasir tufaan, breksi andesit, batugamping dan batupasir napalan memiliki kelas kerentanan seismik kurang rentan.

\section{HASIL DAN PEMBAHASAN}

\section{Hasil Klasifikasi}

Hasil klasifikasi penggunaan lahan pada level 4 dengan skema klasifikasi RSNI 2013 dapat dilihat pada Gambar 2. Dan hasil pemetaan klasifikasi untuk area terbangun lihat Gambar 3. Peta klasifikasi area terbangun diidentifikasikan menjadi peta bangunan berisiko gempabumi.
Penilaian akurasi hasil klasifikasi dilakukan berdasarkan area objek yang dijadikan data referensi. Selanjutnya jumlah piksel pada area objek sebagai data referensi dibandingkan dengan area objek hasil klasifikasi. Hasil penilaian akurasi dapat dilihat pada Tabel 1. Dilihat dari hasil akurasi keseluruhan klasifikasi hierarkis pada citra ALOS pansharpening yaitu $65.4 \%$. Hasil akurasi tersebut termasuk pada kriteria yang rendah.

\section{Hasil Pemetaan Bangunan Berisiko Gempabumi}

Berdasar tabel 1 akurasi produk hasil klasifikasi kelas area terbangun sangat rendah yaitu kurang dari $66,9 \%$. Nilai tertinggi tersebut pada kelas bangunan permukiman desa, area permukiman kota akurasi produk sebesar $51,9 \%$. Dan area yang lain kurang dari $12,5 \%$.

Hasil dari pemetaan bangunan dan infrastruktur yang berisiko gempabumi seperti ditunjukan pada gambar 4. Hasil penilaian bangunan yang berisiko gempabumi dinilai secara kualitatif lebih rentan dan kurang rentan. Bangunan dengan resiko lebih rentan banyak terdapat disisi sebelah barat sesar opak. Dilihat pada gambar 3 bangunan permukiman desa dominan pada daerah bantul dan berisiko lebih rentan terhadap gempabumi.

Akurasi klasifikasi hierarkis dengan segmentasi multiresolusi menggunakan citra ALOS pansharpening untuk memetakan bangunan yang berisiko gempabumi termasuk dalam kriteria rendah. Pembahasan akuarasi yang rendah memperhatikan sisi skala segmentasi yang digunakan, keefektikan klasifikasi hierarkis terhadap penggunaan lahan yang sangat heterogen serta dari sisi sumber data yang digunakan yaitu citra ALOS pansharpening.

\section{Skala Segmentasi Mempengaruhi Hasil Klasifikasi Hierarkis}

Klasifikasi berbasis objek dimulai dengan segmentasi citra. Segmentasi citra yang digunakan dalam penelitian ini adalah segmentasi multiskala atau multiresolusi dimana ditentukan oleh parameter skala, warna dan bentuk. Sebagai awal proses klasifikasi berbasis objek, segmentasi mempengaruhi hasil klasifikasi dengan target skala peta yang ditentukan.

Skala segmentasi yang kecil ditargetkan mendapatkan objek yang lebih detail untuk memisahkan antar objek atau kelas penggunaan lahan pada level 4 klasifikasi penggunaan lahan. Dan level 4 klasifikasi penggunaan lahan ditargetkan untuk skala peta 1:25.000. Gambar 4 menunjukan hasil segmentasi dengan skala yang kecil dimana kedetailan objek yang tersegmen semakin terbentuk. Namun skala segmentasi yang kecil juga mensegmen objek dengan 
ukuran yang besar. Segmen-segmen tersebut membuat nilai fitur objek tersebut berubah dan mengurangi tingkat akurasi klasifikasi. Hal tersebut disebabkan segmen yang terbentuk memiliki nilai fitur yang berbeda baik dari karakteristik spektral, bentuk maupun teksturnya.

Sebagai contoh kasus tersebut adalah stadion dimana terdapat pada level 4 skema klasifikasi. Objek stadion tersegmen menjadi beberapa bagian segmen pada skala segmentasi 50. Dibandingkan segmen yang

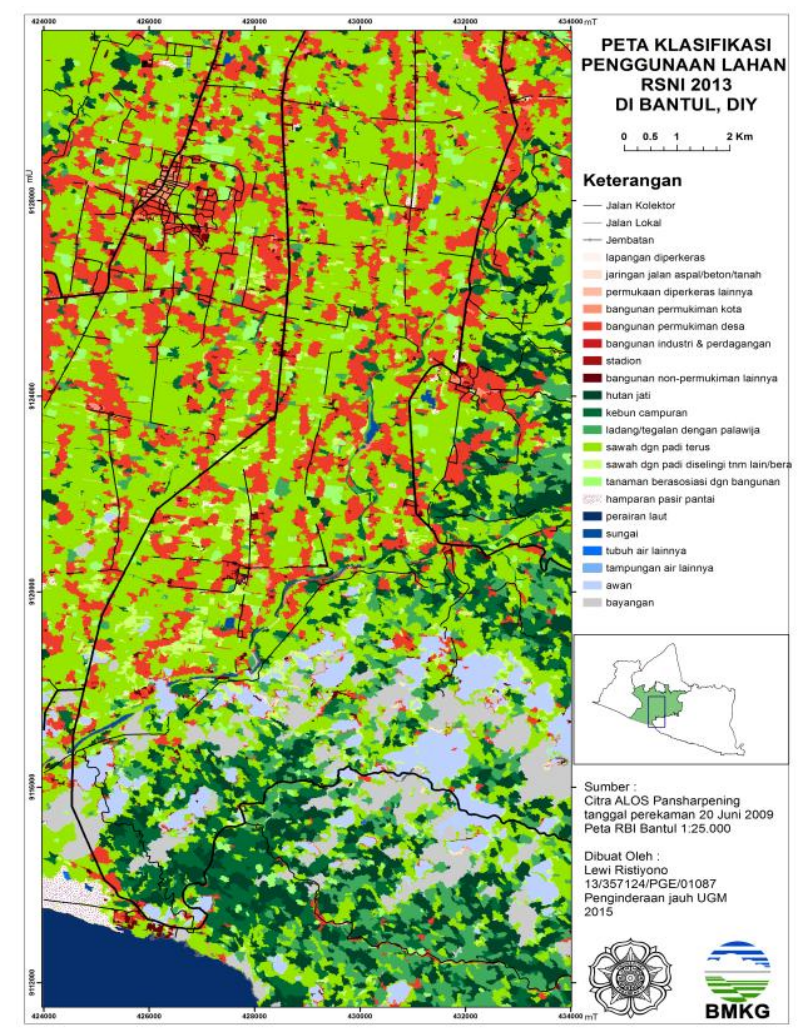

Gambar 2. Peta Klasifikasi Penggunaan Lahan terbentuk pada stadion dengan skala yang lebih besar, lihat Gambar 5. Selanjutnya objek stadion dilakukan proses klasifikasi secara bersamaan dengan objek lain pada level 4 klasifikasi penggunaan lahan. Pemberian nilai fitur bentuk pada objek stadion di rule set menjadikan beberapa segmen-segmen stadion tidak terklasifikasikan sebagai stadion. Dengan demikian dapat diketahui bahwa satu skala segmentasi untuk semua objek pada level 4 klasifikasi kurang baik untuk klasifikasi berbasis objek.

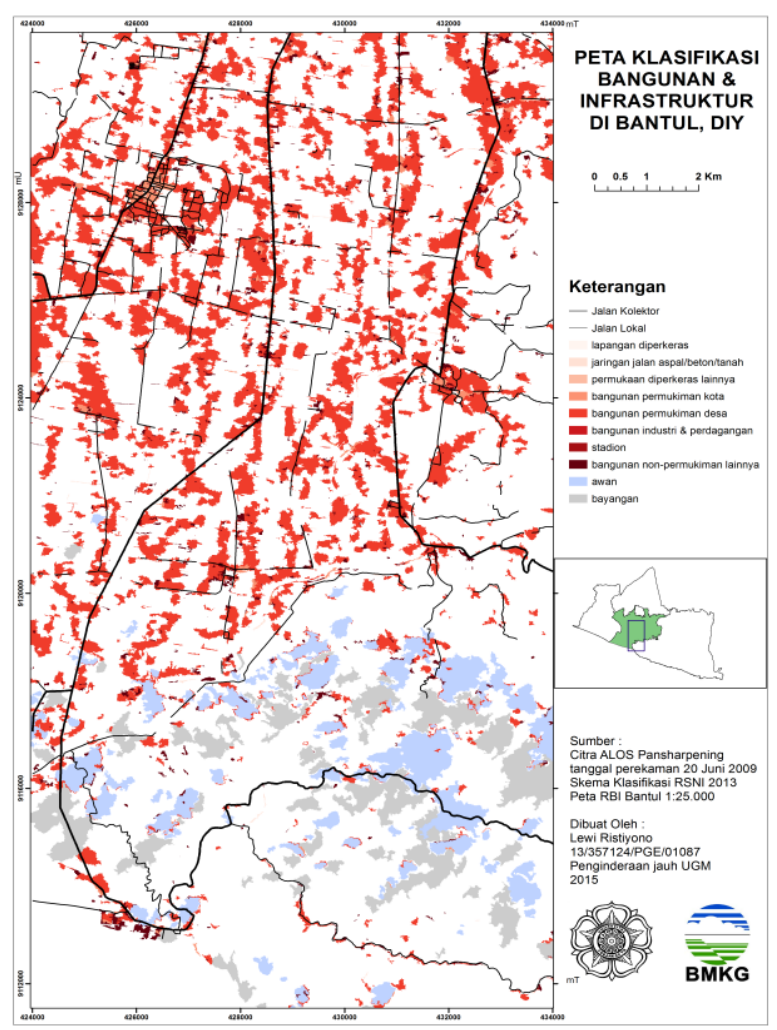

Gambar 3. Peta Klasifikasi Area Terbangun

Tabel 1. Tabel Akurasi Klasifikasi Penggunaan Lahan Dengan Skema RSNI 2013 Perubahan

\begin{tabular}{|c|c|c|c|c|c|c|c|c|c|c|c|c|c|c|c|c|c|c|c|c|c|c|c|}
\hline User \Reference Class & 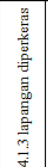 & 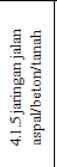 & 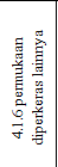 & 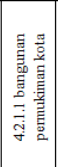 & 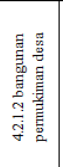 & 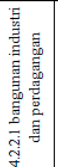 & 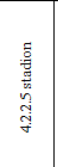 & 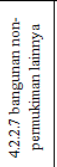 & 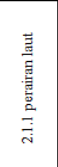 & 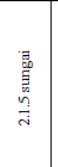 & 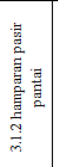 & 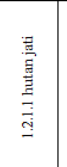 & 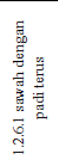 & 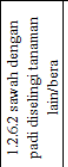 & 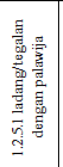 & 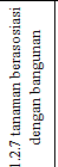 & 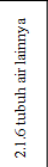 & 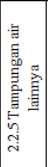 & 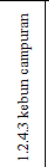 & 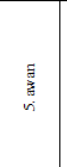 & 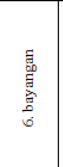 & 馬 & 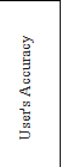 \\
\hline \begin{tabular}{|l|}
4.1 .3 lapangan diperkeras \\
\end{tabular} & 0 & 0 & & & & 0 & & 0 & 0 & & 0 & 0 & 0 & 0 & & 0 & 0 & 0 & 0 & & & 0 & $0.0 \%$ \\
\hline 4.1.5 jaringan jalan aspal/beton/tanah & 0 & 711 & 0 & 0 & 0 & 0 & 0 & 0 & 0 & & 0 & 14 & 34 & 152 & 0 & & & & & & & 917 & $77.5 \%$ \\
\hline 4.1.6 pemukaan diperkeras lainnya & 0 & & 1025 & 0 & 0 & 0 & 0 & 0 & 0 & 0 & 0 & 0 & 0 & 0 & 0 & 0 & 0 & 0 & 0 & 0 & 0 & 1025 & $100.0 \%$ \\
\hline 4.2.1.1 bangunan permukiman kota & 73 & 34 & 95 & 36403 & 5932 & 8 & & 2976 & 66 & 387 & 429 & 0 & 592 & 176 & 0 & 0 & & 0 & 0 & 678 & 297 & 48146 & $75.6 \%$ \\
\hline 4.2 .1 .2 bangunan permukiman des a & 14 & 1340 & 1250 & 23436 & 336015 & 0 & 0 & 14641 & 10 & 4023 & 113 & 4821 & 28506 & 5862 & 1242 & 0 & 2506 & 337 & 168 & 4252 & 9107 & 437643 & $76.8 \%$ \\
\hline 4.2 .2 .1 bangunan industri dan perdagangan & 0 & 0 & 0 & & & 267 & 0 & 883 & 0 & & 0 & 0 & 18 & & 0 & 两 & & 0 & 0 & 0 & 0 & 1184 & $22.6 \%$ \\
\hline 4.2 .25 stadion & 0 & 0 & 867 & 0 & 0 & & 669 & & 0 & & 0 & 0 & 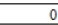 & 0 & 0 & 0 & & 0 & 0 & 0 & 0 & 1536 & $43.6 \%$ \\
\hline 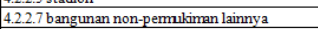 & 12 & 264 & 609 & 2281 & 7840 & 1492 & 21 & 16014 & 15211 & 215 & 360 & 16 & 533 & 522 & 31 & of & & 0 & 0 & 1660 & 335 & $\begin{array}{r}47420 \\
\end{array}$ & $33.8 \%$ \\
\hline 2.1.1 perairan laut & 0 & 0 & 0 & & 0 & 0 & 0 & 0 & 803583 & & 0 & 0 & & 0 & & & & & 0 & & & 803583 & $100.0 \%$ \\
\hline 2.1 .5 sungai & 0 & 0 & 0 & 0 & 0 & 0 & 0 & 111 & 6286 & 45764 & 186 & 185 & 12428 & 0 & 0 & 0 & 0 & 0 & 32 & 0 & 0 & 64992 & $70.4 \%$ \\
\hline 3.1.2 hamparan pasii pantai & 0 & 0 & 0 & 0 & 265 & 71 & 0 & 641 & 1127 & 118 & 7627 & 0 & 2188 & 1398 & & 0 & & 0 & 0 & 431 & 0 & 13866 & $55.0 \%$ \\
\hline 1.2.1.1 hutan jati & 0 & 0 & 0 & 0 & 10549 & 0 & 0 & 141 & 0 & 1691 & & 153777 & 1305 & & 36607 & 0 & & 682 & 0 & 858 & 5421 & 211031 & $72.9 \%$ \\
\hline 1.2.6.1 sawah dengan padi terus & 2648 & 1899 & 4143 & 7963 & 118297 & 74 & 1453 & 9650 & 5838 & 17145 & 7559 & 12178 & 369113 & 99552 & 138067 & & 7367 & 2844 & 52 & 6838 & 56022 & 868702 & $42.5 \%$ \\
\hline 1.2.6.2 sawah dengan padi diselingi tanaman lain/l & & & 168 & & 949 & & & 329 & & 49 & 0 & & 3606 & 15079 & 3490 & & & & 0 & 4020 & 4183 & 31971 & $47.2 \%$ \\
\hline 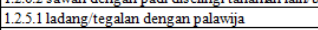 & & 745 & & & 13367 & 0 & & $\frac{32}{4}$ & 0 & 4315 & 0 & 61247 & 3650 & 0 & 77560 & & & 270 & 0 & 1849 & 3466 & 166473 & $46.6 \%$ \\
\hline 1.2.7 tanaman beras osiasi dengan bangunan & 0 & 43 & 15 & & 3525 & 202 & & 70 & 51 & & 384 & 7083 & 23793 & 17075 & 1008 & & 308 & 435 & 1664 & 122 & 1308 & 57086 & $0.0 \%$ \\
\hline $\begin{array}{l}2.1 .6 \text { tubuh air lainnya } \\
\end{array}$ & 0 & 0 & & 0 & 0 & 0 & 0 & 0 & 156 & 0 & 9 & 0 & 0 & 0 & 0 & 0 & & 2253 & 0 & 0 & 0 & 2418 & $0.0 \%$ \\
\hline 2.2 .5 Tampung an air lainnya & 0 & & & 0 & 0 & 0 & 0 & & 0 & & 0 & & & & & 0 & & & 1608 & 0 & & 1608 & $0.0 \%$ \\
\hline 1.2.4.3 kebun campuran & 0 & 0 & 0 & 0 & 5402 & 0 & 0 & 0 & 0 & 2878 & 0 & 101892 & 988 & & 18282 & 0 & & 8 & 0 & 921 & 25707 & 156078 & $0.0 \%$ \\
\hline 5. awan & 0 & 0 & 0 & 0 & 0 & 0 & 0 & 0 & 6730 & 0 & 0 & 0 & 0 & 0 & & 0 & & 0 & 0 & 111494 & 567 & 118791 & $93.9 \%$ \\
\hline 6. bayangan & 0 & 0 & 0 & 0 & 0 & 0 & 0 & 0 & 17755 & 83 & 0 & 821 & & 0 & & 0 & & 1 & 0 & 18 & 66051 & 84732 & $78.0 \%$ \\
\hline Jumlah & 2747 & 5104 & 8172 & 70090 & 502150 & 2114 & 2143 & 45460 & 856813 & 76674 & 16667 & 342061 & 446754 & 139816 & 276290 & 0 & 10188 & 6830 & 3524 & 133141 & 172464 & & \\
\hline Produser's Accuracy & $0.0 \%$ & $13.9 \%$ & $12.5 \%$ & $51.9 \%$ & $66.9 \%$ & $12.6 \%$ & $31.2 \%$ & $35.2 \%$ & $93.8 \%$ & $59.7 \%$ & $45.8 \%$ & $45.0 \%$ & $82.6 \%$ & $10.8 \%$ & $28.1 \%$ & $0.0 \%$ & $0.0 \%$ & $0.0 \%$ & $0.0 \%$ & $83.7 \%$ & $38.3 \%$ & & \\
\hline
\end{tabular}




\section{Keefektifan Klasifikasi Hierarkis}

Klasifikasi berbasis objek dengan klasifikasi hierarkis secara konseptual memudahkan dalam klasifikasi penggunaan lahan. Sebagaimana dijelaskan dalam tinjauan pustaka klasifikasi ini mengelompokkan objek penggunaan lahan berdasarkan karakteristik spektral lebih dahulu dan dilanjutkan dengan karakterisktik spasialnya. Namun untuk wilayah yang heterogen seperti area penelitian ini kurang efektik. Sebagai contoh pembahasan ini adalah sawah pada daerah penelitian. Wilayah sawah yang berbeda karakteristik spektral karena berbeda masa tanam. Untuk pemetaan bangunan juga dinilai kurang efektik sebab di wilayah penelitian memiliki heterogenitas yang tinggi dari bahan atap, bentuk dan distribusinya.

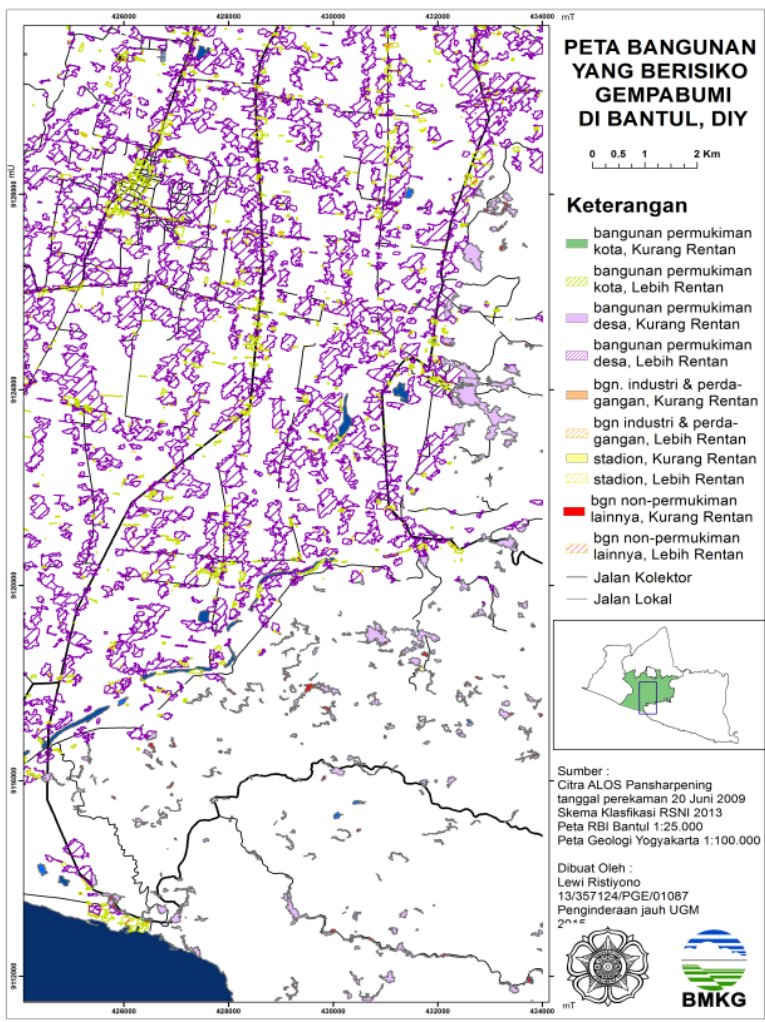

Gambar 4. Peta Bangunan Berisiko Gempabumi

\section{KESIMPULAN}

Berdasarkan hasil dan pembahasan maka penelitian ini dapat disimpulkan menjadi bebeberapa kesimpulan yaitu :

1. Klasifikasi berbasis objek dengan metode klasifikasi hierarkis menghasilkan akurasi yang kecil yaitu $65,4 \%$. Hal ini disebabkan oleh :

(a) Parameter skala segmentasi tunggal untuk semua kelas pada level 4 skema klasifikasi.

(b) Heterogenitas penggunaan lahan di daerah penelitian yang tinggi.

\section{Kemampuan Citra ALOS Pansharpening Terhadap Hasil Klasifikasi}

Sumbur data yang digunakan dalam klasifikasi berbasis objek mempengaruhi hasil yang diperoleh. Penelitian ini menggunakan citra ALOS pansharpening dimana memiliki kelebihan di resolusi spasial. Namun ALOS pansharpening memiliki kelemahan yaitu terjadi distorsi spektral. Distorsi spektral mempengaruhi nilai fitur objek. Hal ini selaras dengan hasil peneilitian Lewinski (2006) dengan pansharpen ETM+ yang menyatakan bahwa pengguna data fusion tidak memberikan hasil yang signifikan dalam klasifikasi berbasis objek. Dan Witharana et al., (2014) dengan GEOEye-1 yang menyatakan penggunaan citra pankromatik lebih baik dibandingkan citra pansharpening untuk klasifikasi berbasis objek dengan rule set.

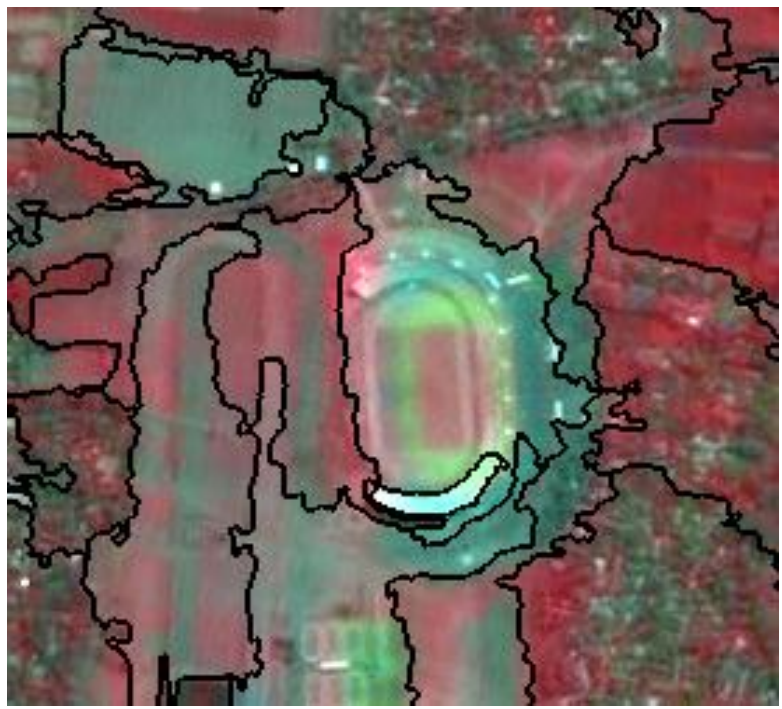

Gambar 5. Segmentasi pada Stadion dengan Skala Segmentasi 100 (c) Distorsi spektral pada citra ALOS pansharpening sebagai sumber data.

2. Tingkat akurasi distribusi spasial bangunan yang berisiko gempabumi dimana pemetaan bangunannya melalui klasifikasi penggunaan lahan ditentukan oleh tingkat akurasi klasifikasi penggunaan lahan.

\section{DAFTAR PUSTAKA}

ALOS User Handbook. Diakses pada tanggal 29 September 2014 
http://www.eorc.jaxa.jp/ALOS/en/doc/alos_userhb _en.pdf.

Baatz, M., dan Schäpe, A. (2000). "Multiresolution segmentation - an optimization approach for high quality multi-scale image segmentation" dalam Angewandte Geographische Informations verarbeitung XII. Diedit oleh Strobl, Blaschke dan Griesebner, Wichmann-Verlag, Heidelberg. pp. 12-23.

Benz, Ursula C., Hofmann, P., Willhauck, G., Lingenfelder, I., Heynen, M. (2004). Multi-resolution, object-oriented fuzzy analysis of remote sensing data for GIS-ready information. ISPRS Journal of Photogrammetry \& Remote Sensing. 58, 239-258.

Blaschke, T. (2010). Object based image analysis for remote sensing. ISPRS Journal of Photogrammetry and Remote Sensing. 65 (1), 2-16.

Blaschke, T., Burnett, C., Pekkarinen, A. (2004). Image Segmentation Methods for Object-based Analysis and Classification, dalam Remote Sensing Image Analysis: Including the spatial domain, Diedit oleh DeMeer, F. and de Jong, S., Kluver Academic Publishers, Dordrecht, pp. 211-236.

Blaschke Thomas, Geoffrey J. Hay, Maggi Kelly, Stefan Lang, Peter Hofmann, Elisabeth Addink, Raul Queiroz Feitosa, Freek van der Meer, Harald van der Werff, Frieke van Coillie, Dirk Tiede. (2014). Geographic Object-Based Image Analysis Towards a new paradigm. ISPRS Journal of Photogrammetry and Remote Sensing. 87, 180-191.

Burnett, C., dan Blaschke Thomas. (2003). A multi-scale Segmentation/Object Relationship Modelling Methodology For Landscape Analysis. Ecological Modelling. 168 (3), 233-249.

Danoedoro, Projo. (2012). Pengantar Penginderaan Jauh Digital. Yogyakarta : Andi Offset.

Danoedoro, P. (2009). Land-Use Information From The Satellite Imagery: Versatility and Contents For Local Physical Planning. Lambert Academic Publishing AG \& Co. KG.

Drăguţ L., O. Csillik, C. Eisank, D. Tiede. (2014). Automated parameterisation for multi-scale image segmentation on multiple layers. ISPRS Journal of Photogrammetry and Remote Sensing. 88, 119-127.

Hay, G.J., Castilla, G. (2008). Geographic Object-Based Image Analysis (GEOBIA): A new name for a new discipline. In: Blaschke, T., Lang, S., Hay, G. (Eds.), Object Based Image Analysis. Springer, Heidelberg, Berlin, New York, pp. 93-112.

Lewinski Stanislaw. (2006). Applying fused multispectral and panchromatic data of Landsat $\mathrm{ETM}+$ to object oriented classification. Proccedings of the 26th EARSeL Symposium, New Developments and Challenges in Remote Sensing. May 29-June 2, 2006. Warsaw, Poland.

M. Wieland, M. Pittore, S. Parolai, J. Zschau, B. Moldobekov, U. Begaliev. (2012). Estimating building inventory for rapid seismic vulnerability assessment: Towards an integrated approach based on multi-source imaging. Soil Dynamics and Earthquake Engineering. 36, 70-83.

Masroor Hussain, Dongmei Chen, Angela Cheng, Hui Wei, David Stanley. (2013). Change detection from remotely sensed images: From pixel-based to object-based approaches. ISPRS Journal of Photogrammetry and Remote Sensing. 80, 91-106.

Schiewe, J. (2002). Segmentation of high-resolution remotely sensed data-concepts, applications and problems. International Archives of Photogrammetry Remote Sensing And Spatial Information Sciences. 34 (4), 380-385.

Soe W. Myint, Patricia Gober, Anthony Brazel, Susanne Grossman-Clarke, Qihao Weng. (2011). Per-pixel vs. object-based classification of urban land cover extraction using high spatial resolution imagery. Remote Sensing of Environment. 115, 1145-1161.

Timothy G. Whitesidea, Guy S. Boggs, Stefan W. Maier. (2011). Comparing object-based and pixel-based classifications for mapping savannas. International Journal of Applied Earth Observation and Geoinformation. 13, 884-893.

Varnes David, J. (1984). Landslide Hazard Zonation: A Review Of Principles and Pratice. Published 1984 by United Nations Educational, Scientific and Cultural Organization, 7 Place de Fontenoy, 75700 Paris, ISBN 92-3-101895-1.

Witharana, Chandi dan Daniel L. Civco dan Thomas H. Meyer. (2014). Evaluation of data fusion and image segmentation in earth observation based rapid mapping workflows. ISPRS Journal of Photogrammetry and Remote Sensing. 87, 1-18. 